\title{
Costs of inguinal hernia repair associated with using different medical devices in the Czech Republic
}

This article was published in the following Dove Press journal:

Therapeutics and Clinical Risk Management

26 October 2016

Number of times this article has been viewed

\author{
Petra Marešová \\ Matus Peteja ${ }^{2}$ \\ Milan Lerch ${ }^{2}$ \\ Pavel Zonca ${ }^{2}$ \\ Kamil Kuca ${ }^{3}$ \\ 'Department of Economics, Faculty \\ of Informatics and Management, \\ University of Hradec Kralove, \\ Hradec Kralove, ${ }^{2}$ Department of \\ Surgical Studies, Faculty of Medicine, \\ University of Ostrava, Ostrava, \\ ${ }^{3}$ Center of Basic and Applied \\ Research, Faculty of Informatics and \\ Management, University of Hradec \\ Kralove, Hradec Kralove, Czech \\ Republic
}

Objective: Inguinal hernia repair is one of the most frequently carried out operations worldwide. The purpose of this article is to analyze the costs of hernia repair and to specify the loss or profit made under the conditions in the Czech Republic with respect to the currently used medical devices and approaches.

Methods: This article is based on the Drummond and O'Brien methodology, which specifically determines the content of direct and indirect costs in health services. The costs of operations during the period 2010-2014 were specified for a total of 746 patients. The cost details are described for four patients who represent the use of different types of medical devices. The procedure was a laparoscopic surgery in all cases.

Results: The total costs of inguinal hernia repairs (as per 2015 currency conversion rate) are $€ 1,248,579$; only part is covered from public funds, resulting in a loss of $€ 218,359$ for the hospital. The obtained data indicate that this operation is unprofitable for hospitals under the present conditions. The loss in the subject facility amounts to $17 \%$ of the total cost, which is the cost incurred by the hospital in the Czech Republic.

Conclusion: The study conducted in the Czech Republic refers to different economic results when using various medical device types. So the medical device selection depends on advantages or disadvantages for the patients, as well as on the cost effectiveness for the hospital.

Keywords: hernia, laparoscopy, cost, medical device, Czech Republic

\section{Introduction}

Inguinal hernia repair is one of the most frequently carried out operations worldwide. ${ }^{1}$ Approximately 700,000 operations a year are performed in the US, 100,000 in France, 80,000 in the UK, and 15,000 in the Czech Republic. ${ }^{2}$

The most frequent cases encountered include indirect inguinal hernia $(\sim 50 \%)$ and direct inguinal hernia $(\sim 25 \%)$, in both children and adults. ${ }^{3}$ As far as the occurrence is concerned, this is followed by hernia in postoperative scars, femoral hernia, and so on. There are $\sim 35,000$ patients diagnosed and hospitalized with hernia in the Czech Republic every year. Numerous studies have proven the advantages of laparoscopic surgery compared the open approach. ${ }^{4-8}$ They include: reduced postoperative pain, reduced need for narcotics, and faster recovery. Laparoscopic surgery also has some disadvantages, including higher costs, longer operation time, and more complications in case of inexperienced surgeons.

According to comparative studies, the winner is the "tension-free" approach, ie, an approach free of tension using a mesh made of synthetic material, the so-called biomaterial (abbreviation for biocompatible material), most often polypropylene, polyethylene,
Correspondence: Kamil Kuca Center of Basic and Applied Research, Faculty of Informatics and Management, University of Hradec Kralove, Rokitanského 62, 50003, Hradec Kralove, Czech Republic Email kamil.kuca@uhk.cz 
or polyester at present. There are two mesh implantation approaches, the first is cutting cutis, the second is laparoscopy by three minor incisions (one $10 \mathrm{~mm}$ and two $5 \mathrm{~mm}$, or two $10 \mathrm{~mm}$ and one $5 \mathrm{~mm}$ ). Most of the medical facilities in the Czech Republic country have been implanting the mesh in a conventional manner in most cases. However, the trend is changing from the conventional operations to the minimally invasive laparoscopic operations. The mesh implantation using the modern minimally invasive laparoscopic approach is often more demanding in terms of both technical equipment and primarily the experience and skills of the surgeon. ${ }^{9}$

The purpose of this article is to analyze the costs of hernia repair and to specify the loss or profit made under the conditions in the Czech Republic with respect to the currently used medical devices and approaches.

The problem is analyzed taking into account the legislative and economic conditions in the Czech Republic. There were 2,330,000 patients hospitalized in 2012, and the average duration of stay in a medical facility ranged from 9.0 days to 9.3 days. A total of 650,000 patients were operated on, which is $\sim 29.6 \%$ of the total number, and $17.1 \%$ were emergency cases, which is a relatively high percentage that would certainly deserve further analysis. Hernia repairs represent $24 \%$ of the total number of operated patients. There were 35,310 patients hospitalized with this diagnosis, with an average age of 50.3 years. The duration of their average stay in a medical facility was 4.1 days. As far as occurrence of the individual hernia types is concerned, inguinal hernia comes first, representing about one-third of all hernia repairs. The statistics also include payments for hernia repairs. Children's inguinal hernia repair costs CZK 23,000-29,000; tension-free inguinal inguinal hernia repair is generally valued less by the medical care payer, followed by ventral or parastomal hernia. ${ }^{10}$

Regarding the present situation, when laparoscopic repair is preferred more and more, the study in the Czech Republic will deal with the costs in relation to this approach and with various types of medical devices.

\section{Methods}

The article is based on the Drummond and O'Brien methodology. ${ }^{11}$ The costs are split into two categories. The first category comprises the costs of creating and operating a medical program, regarding the costs as resources used. It includes both variable and fixed costs and it is often called direct costs. The other category includes the costs incurred by the patients and their families. Besides the direct costs, it also includes the costs of the working time lost when undergoing the treatment. These production losses are identified as indirect costs of the service or program. The "mental costs" (or mental damage) have a similar character, as they are not negligible in the decision-making process of the patients and their families. However, these indirect costs are not the subject of this paper. The paper describes the costs of operations during the period 2010-2014 for a total of 746 patients. The detailed costs will be specified for four patients who represent the use of various types of medical devices. Laparoscopic surgery was used in all cases.

The total number of patients using Hernia $^{\mathrm{TM}}$ (Medtronic Ltd, Watford, UK) stapler was 207, ProTac ${ }^{\mathrm{TM}}$ (Medtronic Ltd) 57, self-fixating mesh 334, and adhesive fixation 163. Each of the four chosen patients fully represent the group of patients with the same medical device.

The "Hernia stapler" was used in patient 1. The principle of the stapler is that the mesh is laid in its place and fixed with staples to the surrounding tissues. Its advantages mainly include the ease of use because the mesh can be laid in place repeatedly. Disadvantages include possible injury of the vessel or nerve, and the consequent chronic burn in the groin and, in the Czech Republic, even the price. A technical disadvantage is the possibility to fixate only along the mesh circumference and only on three sides (not on the side with large vessels).

"ProTac" was used in patient 2. It is an applicator that lays the mesh in its place, fixating it with metal spirals to the surrounding tissues. Fixation to the bone is better than in case of Hernia stapler. The disadvantages are the same as those of the previous medical device.

Adhesive fixation (Glubran, a tissue skin adhesive) was used for patient 3 , where the mesh is laid in place and fixed using a special tissue skin adhesive. The mesh position can be repeatedly adjusted before applying the adhesive without the risk of damaging tissues, vessels, and nerves. It can also be fixated even in the middle of the mesh and on all sides, even in the area of large vessels. Handling the adhesive requires caution so as to avoid adhesion to any undesired organ. The price is higher than for the self-fixating mesh.

The last type of the medical device used is the ProGrip ${ }^{\text {TM }}$ (Medtronic Ltd) self-fixating mesh that is fixated all over the area. It does not damage tissues, vessels, and nerves. Working with this device requires surgeon's skills, because the mesh cannot be positioned repeatedly: it is fixed with hooks on the contact side right after it is laid for the first time.

Reimbursement of costs from public funds is specified primarily in Law number 48/1997 Coll on public health insurance and amending and supplementing some related acts. The aforementioned law provides a range of health care fully covered, partially covered, or not covered by 
Table I Number of patients with hernia repair in the period from 2010 to 2014

\begin{tabular}{ll}
\hline Year & Number of patients \\
\hline 2010 & 157 \\
2011 & 160 \\
2012 & 197 \\
2013 & 119 \\
2014 & 113 \\
Total & 746 \\
\hline
\end{tabular}

public health insurance. Key for setting prices (reimbursement) is Decree number 134/1998 Coll, which publishes a list of medical procedures with point values (last amended is Decree number 472/2009 Coll). Each year, the values of the items are updated. Ethical approval was not sought as all four types of operations used are legally established in the Czech Republic and paid for by insurance companies. Written informed consent was not obtained as all data were anonymous, and the study used retrospective data.

\section{Results: cost of hernia repair with respect to different types of medical devices}

Situation concerning the cost of hernia repair in the Czech Republic will be supported with the current price details of 2015 with comparison of four medical devices: Herniastapler, Glubran (tissue skin adhesive), ProTac, and the self-fixating mesh. The data of the University Hospital of Ostrava during the period 2010-2014 have been used, from 746 patients in the study. The number of patients in the individual years is shown in Table 1.

\section{Cost of hernia repair}

Table 2 contains the costs of hernia repairs in four patients, falling in the category of "one side or undefined inguinal hernia without continuity failure or gangrene", with prices in the individual years when the patients were hospitalized. It includes the costs of repair, total costs, and operating result made by the hospital after deduction of the cost of item reimbursed by the insurance company.
If the cost values were converted to the prices under conditions of the year 2015, the results would be as shown in Table 3.

Decline in prices (reimbursement costs) in the Czech health care system shows that the use of self-fixating mesh is appropriate and economically preferable. More detailed specifications are listed in the following section (Tables 4 and 5).

\section{Detailed specification of direct costs}

The items reported are almost identical for all four patients; the major differences are found in the prices of the medical devices and their accessories (Table 5).

The total costs for all patients in the past 5 years can be calculated only roughly based on the average values. The total costs in converted prices of 2015 amount to $\sim € 1,248,579$, of which the operating result for the hospital is the loss amounting to $\sim 218,359$.

\section{Discussion}

Numerous studies deal with specification of the costs of hernia repairs. Early studies have focused on comparing laparoscopic surgery with the open procedure. Further studies are focused on analyzing complications associated with the individual surgery types.

One of the earlier studies by LeBlanc and LeBlanc ${ }^{12}$ refers to the need of monitoring the cost effectiveness of surgeries and provides methodical guidelines for recording and analyzing the surgeries. Use of the proposed methodological guideline is presented on inguinal hernia repair. The authors made a structured set of questions, leading to possible calculations of profits or losses of such repairs. In this case study, the hernia repair is loss making in case of both laparoscopic and open surgery.

The purpose of the study conducted by Eklund et a $1^{13}$ was to compare the long-term costs of laparoscopic and open inguinal hernia repairs, including the costs of managing postoperative complications. A total of 1,370 patients were included in their study over 5 years. Comparison of the two above-mentioned approaches demonstrated that the

Table 2 Cost of repair for individual patients (EUR)

\begin{tabular}{llllll}
\hline $\begin{array}{l}\text { Patient } \\
\text { identification }\end{array}$ & Hospitalization & $\begin{array}{l}\text { Length } \\
\text { of stay (days) }\end{array}$ & $\begin{array}{l}\text { Costs of } \\
\text { repair }\end{array}$ & $\begin{array}{l}\text { Total } \\
\text { costs }\end{array}$ & $\begin{array}{l}\text { Difference } \\
\text { (reimbursement - costs) }\end{array}$ \\
\hline Patient I & March 23, 2010 to March 25, 20I0 & 3 & 699.0 & $2,158.2$ & $-1,261.3$ \\
Patient 2 & April 26, 2010 to April 28, 2010 & 3 & 714.7 & $1,542.2$ & -645.3 \\
Patient 3 & October 31, 2012 to November 2, 2012 & 3 & 786.0 & $1,653.5$ & -476.3 \\
Patient 4 & September 5, 2013 to September 9, 2013 & 5 & 853.7 & $1,328.9$ & -112.7 \\
\hline
\end{tabular}


Table 3 Details converted to values of costs and reimbursement under conditions of year 2015 (EUR)

\begin{tabular}{llll}
\hline $\begin{array}{l}\text { Patient } \\
\text { identification }\end{array}$ & $\begin{array}{l}\text { Costs of } \\
\text { repair }\end{array}$ & $\begin{array}{l}\text { Total } \\
\text { costs }\end{array}$ & $\begin{array}{l}\text { Difference } \\
\text { (reimbursement - costs) }\end{array}$ \\
\hline Patient I & 655.2 & $2,156.3$ & -808.8 \\
Patient 2 & 668.3 & $1,512.4$ & -127.8 \\
Patient 3 & 831.7 & $1,699.2$ & -291.8 \\
Patient 4 & 851.6 & $1,326.8$ & 57.7 \\
\hline
\end{tabular}

laparoscopic inguinal hernia repair had significantly higher total costs compared to open repair. ${ }^{13}$

The study by Reynolds et $\mathrm{al}^{14}$ is focused on the specification of direct and indirect costs related to 415 patients. The results refer to the loss made by these repairs, whereas significantly higher losses are observed in cases when the hernia repair was a secondary intervention. The mean value of loss made by repair (without mesh) was USD500. The profit made by synthetic-mesh-based repairs amounted to USD60. The mean value of the assistance toward the costs in case of using the biologic mesh was USD -4.560 , and the median of the net financial loss was USD8.370. ${ }^{14}$ The study by Denoto et al focuses on the costs of repair of potentially contaminated/infected complex ventral hernias using primary repair, synthetic mesh, or acellular xenograft. The analysis was conducted based on data of 740 patients obtained from the insurance company's records. The analysis indicates that the total 18-month costs were similar in all three analyzed cases using different medical devices. ${ }^{15}$
The conducted case study in the Czech Republic including 746 patients indicates that situation in the Czech Republic corresponds with those of the other economies. A detailed analysis revealed that the use of the medical device ProGrip self-fixating mesh is economically the most advantageous based on comparison of the 2015 prices and medical device types. However, this medical device imposes the highest requirements for the surgeons' skills. The prices of the individual medical devices cannot be specified precisely due to possible change in prices of the respective suppliers, based on quantity for instance.

Generally, the hospitals report the repairs as loss making. This conclusion can be accepted despite the limits of this study, which mainly affect the calculation of the total loss for the past years of observations. In the subject facility, the loss or cost paid by the hospital amounted to $17 \%$ of the total cost. This confirms the results of other studies.

\section{Conclusion}

International comparison of prices for the care provided should be done with high caution, as such comparisons are based on different reimbursement systems and expert estimates. Generally, we can make a conclusion based on comparison with the international studies from the past years ${ }^{11-13}$ pointing to the loss made by these repairs. Study in the Czech refers to different economic results when using various medical device types and shows a loss too. The use

Table 4 Breakdown of interventions and medical devices in case of patient I (based on the current prices of 2015 in EUR)

\begin{tabular}{|c|c|c|c|}
\hline Items & Medical procedures and medical devices & Quantity & Cost, EUR \\
\hline 00602 & Hospitalization & 2 & 125.8 \\
\hline 51021 & Complex examination by surgeon & I & 28.1 \\
\hline 51022 & Targeted examination by surgeon & I & 15.5 \\
\hline $5|7| \mid$ & Laparoscopic and thoracoscopic operation & 2 & 273.3 \\
\hline 78023 & Control examination by anesthetist & I & 10.0 \\
\hline 78116 & Anesthesia with controlled ventilation in 20 -minute intervals & 5 & 133.6 \\
\hline 78121 & Capnometry during anesthesia in 20-minute intervals & 5 & 42.8 \\
\hline 78820 & Airways securing during anesthesia & I & 7.8 \\
\hline KAT-3 & Patient with close supervision required & I & 7.0 \\
\hline KAT-4 & Immobile patient & I & 11.2 \\
\hline Total & & 20 & 655.2 \\
\hline \multicolumn{4}{|c|}{ Hernia $^{\mathrm{TM}}$ stapler } \\
\hline 0030645 & Reservoir for linear Stapler MF Endo Hernia & I & 105.6 \\
\hline 0053503 & Point for Trokar Versaport RT $10 \mathrm{~mm} \mathrm{N.SH}$ & I & 150.3 \\
\hline 0053531 & Stapler Endo Universal $65^{\circ} 12 \mathrm{~mm}$ & I & 377.8 \\
\hline 0058162 & Scissors curved 5DCS & I & 200.6 \\
\hline 0058163 & Dissector curved 5DCD & I & 200.6 \\
\hline 0058363 & Hernioplasty on one side DRG 90796 & I & 457.4 \\
\hline Total & & 6 & $\mathrm{I}, 492.2$ \\
\hline
\end{tabular}


Table 5 Variable costs of various medical devices used

\begin{tabular}{|c|c|c|c|}
\hline Patient 2 & Type of medical devices & Quantity & Cost, EUR \\
\hline \multicolumn{4}{|l|}{ Medical device, ProTac ${ }^{\mathrm{TM}}$} \\
\hline & Stapler Endo Universal $65^{\circ} 12 \mathrm{~mm}$ & 1 & 377.8 \\
\hline \multicolumn{4}{|l|}{ Patient 3} \\
\hline \multicolumn{4}{|l|}{ Medical device, adhesive fixation } \\
\hline & Scissors curved 5DCS & I & 200.6 \\
\hline & Dissector curved 5DCD & I & 200.6 \\
\hline Total costs of adhesive fixation & & & 401.2 \\
\hline \multicolumn{4}{|l|}{ Patient 4} \\
\hline \multicolumn{4}{|l|}{ Medical device, self-fixating mesh } \\
\hline & ProGrip ${ }^{\mathrm{TM}}$ mesh & I & ||$|-| 8 \mid$ \\
\hline
\end{tabular}

of some types of medical devices is more expensive and sometimes unprofitable for the hospital. Reimbursement for their use depends on the discussion in the context of legislative rules, which is a long-term problem.

\section{Acknowledgments}

This research was supported by Project Excellence (University of Hradec Kralove) and the Internal Research Economic and Managerial Aspects in Biomedicine, Longterm Development Plan University of Ostrava.

\section{Disclosure}

The authors report no conflicts of interest in this work.

\section{References}

1. Jenkins JT, O’Dwyer PJ. Inguinal hernias. BMJ. 2008;336(7638): 269-272.

2. Rutkow IM. Demographic and socioeconomic aspects of hernia repair in the United States in 2003. Surg Clin North Am. 2003; 83(5):1045-1051, v-vi.

3. Numanoğlu KV, Ayoğlu H, Tatlı D, Er E. Efficacy of tramadol as a preincisional infiltration anesthetic in children undergoing inguinal hernia repair: a prospective randomized study. Ther Clin Risk Manag. 2014;10:753-758.

4. Kark AE, Kurzer MN, Belsham PA. Three thousand one hundred seventyfive primary inguinal hernia repairs: advantages of ambulatory open mesh repair using local anesthesia. J Am Coll Surg. 1998;186(4):447-455.

5. Novitsky YW, Czerniach DR, Kercher KW, et al. Advantages of laparoscopic transabdominal preperitoneal herniorrhaphy in the evaluation and management of inguinal hernias. Am J Surg. 2007;193(4):466-470.
6. Takata MC, Duh QY. Laparoscopic inguinal hernia repair. Surg Clin North Am. 2008;88(1):157-178.

7. Memon MA, Cooper NJ, Memon B, Memon MI, Abrams KR. Metaanalysis of randomized clinical trials comparing open and laparoscopic inguinal hernia repair. Br J Surg. 2003;90(12):1479-1492.

8. McCormack K, Scott NW, Go PM, Ross S, Grant AM. Laparoscopic techniques versus open techniques for inguinal hernia repair. Cochrane Database Syst Rev. 2003;(1):CD001785.

9. Hernia Center Praha. Laparoskopické ošetřeni třiselné kýly [Laparoscopic treatment of inguinal hernia]; 2015. Available from: http://www. egk.cz/www/cz/kyla-centrum-historie.phtml?tid=3. Accessed May 1, 2016. Czech.

10. Gryga A, Bureš T, Kohoutek L. Pročje Česká herniologická společnost také sekci ČCHS? [Why is the Czech herniologická company also sections ČCHS?].; 2014. [updated May 2, 2014; cited March 15, 2016]. Available from: http://www.chsp.cz/cz/editorial. Accessed May 1, 2016. Czech.

11. Drummond MF, O’Brien BJ. Methods for the Economic Evaluation of Health Care Programs. Oxford: Oxford Medical Publications; 1997.

12. LeBlanc KA, LeBlanc ZZ. A cost and profit analysis of hernia surgery. JSLS. 1999;3(4):305-314.

13. Eklund A, Carlsson P, Rosenblad A, et al. Long-term cost-minimization analysis comparing laparoscopic with open (Lichtenstein) inguinal hernia repair. Br J Surg. 2010;97(5):765-771.

14. Reynolds D, Davenport DL, Korosec RL, Roth JS. Financial implications of ventral hernia repair: a hospital cost analysis. $J$ Gastrointest Surg. 2013;17(1):159-166.

15. DeNoto G, Reaven N, Funk S. Ventral hernia: retrospective cost analysis of primary repair, repair with synthetic mesh and repair with acellular xenograft implant. Open Access Surgery. 2013;6:23-32.
Therapeutics and Clinical Risk Management

\section{Publish your work in this journal}

Therapeutics and Clinical Risk Management is an international, peerreviewed journal of clinical therapeutics and risk management, focusing on concise rapid reporting of clinical studies in all therapeutic areas, outcomes, safety, and programs for the effective, safe, and sustained use of medicines. This journal is indexed on PubMed Central, CAS,

\section{Dovepress}

EMBase, Scopus and the Elsevier Bibliographic databases. The manuscript management system is completely online and includes a very quick and fair peer-review system, which is all easy to use. Visit http://www.dovepress.com/testimonials.php to read real quotes from published authors. 